\title{
Privacy and Censorship: Another Look
}

\section{William Buck}

To cite this article: William Buck (2015) Privacy and Censorship: Another Look, Library Collections, Acquisitions, \& Technical Services, 39:3-4, 68-72, DOI:

$10.1080 / 14649055.2016 .1214520$

To link to this article: https://doi.org/10.1080/14649055.2016.1214520

Accepted author version posted online: 26 Jul 2016.

Published online: 01 Sep 2016.

Submit your article to this journal

Цll Article views: 543

Q View related articles $\sqsubset$

View Crossmark data \lceil 


\title{
Privacy and Censorship: Another Look
}

\author{
William Buck \\ Texas State Library and Archives Commission, Talking Book Program, Austin, Texas, USA
}

\begin{abstract}
A traditional expectation for publicly funded libraries is that they should be institutions where patron records are kept confidential and a standard of privacy is maintained. After the events of 911, methods increasing search and surveillance powers and reducing legal protections were drafted into law as the "Patriot Act." Searching patron records can be rendered ineffective by library procedures that keep identifiable information to a minimum. Librarians must make responsible collection development decisions while avoiding the pitfalls of censorship. Information has value, and can help or hinder those in the pursuit of goals. Outsourcing collection development decisions is, therefore, not an ideal practice. Librarians should use their training and experience in the selection of information materials.
\end{abstract}

Keywords: privacy, censorship, Patriot Act, collections, information

\section{INTRODUCTION}

The mission of libraries in the $21 \mathrm{st}$ century has been the subject of intense scholarly attention and debate. The ongoing development of Internet access and changing perceptions about what is economically justifiable or relevant to library collections have led to structural and organizational adjustments to the information profession. Nevertheless, there are historically familiar issues that remain, cast now in the new light of developing trends. Two such issues are the perennial questions of privacy and censorship. These issues are directly relevant to a librarian's job duties and are closely tied to collection development strategies. This article offers a brief consideration of these important topics, as well as a review of the controversial Patriot Act. Some examples of library guidelines for protecting patron records are also provided.

\section{Privacy}

Protecting the activity of information seekers in an educational or public environment has always been an important component of the library's mission. There has long been a lively debate about what constitutes privacy, and the

(C) William Buck

Address correspondence to William Buck, Texas State Library and Archives Commission, Talking Book Program, 4400B Shoal Creek Boulevard, Austin, TX 78756. E-mail: williambuck@my.unt.edu differences between privacy and confidentiality. Privacy as a concept can be understood in several different ways, including but not limited to the intrusion into a person's private affairs and spreading libel about a person. Confidentiality is the less problematic of the two concepts, and is usually defined as keeping identifiable information about patrons acquired by circulation records and library card registrations inaccessible to third party agents (ALA.org, 2002). This is a commonly agreed upon practice and is generally understood to be the library's responsibility. In this context confidentiality can be understood as the ability to manage information about oneself. Examples include those who are trying to build a professional reputation, those who keep their medical records confidential to avoid being discriminated against due to their conditions, individuals seeking self-improvement or technical knowledge without interference from inserted representatives or intermediaries, and voters or activists avoiding those who would harass or punish them due to their political affiliations.

In contrast to these types of protections, privacy is here understood as the ability to inquire or research topics without interference. Privacy is considered by most legal scholars to be a right protected by guarantees in the First and Fourth amendments. The Supreme Court decision that pertains directly to libraries is Stanley v. Georgia which defended "the right to be free from state inquiry into the contents of one's library" (Stanley v. Georgia, 1969). Similar decisions have also been made regarding bookstores (Robertson, 2011). As with most everything that is associated with the Internet, questions of online privacy are in a state of flux. There is currently 
little or no guarantee of privacy for anyone who is engaging in online activity. Due to the lack of legal precedence for online privacy, many technology companies actively resist requests for data on user activities. The fear of establishing a precedent that weakens privacy rights is one of the central motivations in Apple Incorporated's dispute with the Federal Bureau of Investigation (Issac, 2016). The protection of library patron records from various online sources, including government and marketing spyware, is one of the more important topics facing library professionals today. This can be easily inferred by the rewarding of significant grants to study these issues, such as the Andrew W. Mellon foundation's grant to the National Information Standard Organization to develop a framework document on privacy issues in the digital domain (NISO, 2016). Much of the discussion by those participating in the initiative centers on balancing the needs for improving services and developing new functionality with privacy concerns.

How could one go about justifying a rigorous policy on patron privacy to those who-for reasons ranging from national security to personal benefit-might object? One method is to point out that it is the librarian's duty to provision the ways and the means whereby thoughtful inquiry is possible. Being able to carry out research without fear of interference is a simple and effective defense of privacy. The extreme cases of interference or censorship by political radicals or religious zealots are easy to defend against, but there are more complicated cases involving national security and the safety of minors. In these cases, the legitimacy of the research project has to be evaluated and there are many in the library profession who may not feel comfortable in that role. Librarians shouldn't be required to make these decisions-in fact it is most likely inappropriate to do so without a formal policy (Murray, 2003). In circumstances where law enforcement or government officials are providing documents for the release of patron records, such as a subpoena, the advice of legal counsel may be necessary.

\section{Government Legislation}

Extensive legislation was passed shortly after the events of 911. Referred to under the umbrella term "USA Patriot Act," the legislation provided for unprecedented search and surveillance powers. The broad surveillance powers, particularly in regards to information agencies, seemed to many critics to have little or no relationship to terrorism threats (The USA Patriot Act, 2016). What was considered worse was the absence of accountability measures built into the surveillance operations. This opened an obvious potential for abuse, providing as it did much easier access to formerly confidential financial, business, and personal records. Under usual circumstances, a subpoena is required to obtain this type of information, and subpoenas can be challenged by the recipients. A judge would then rule on the credibility of the objections, thereby insuring a level of accountability for both parties. Subpoenas in this sense, as opposed to the newly coined "administrative subpoenas," were not required when operating under the Patriot Act. Administrative subpoenas, requiring no judicial oversight, allowed the FBI to secretly obtain library records of patrons not suspected of criminal activity. Such a subpoena was known to have been used in Connecticut (ALA.org, 2005). Other reduced threshold requirements included section 215, which allowed the power to seize library and bookstore records. The number of ways the Patriot Act compromised the privacy of citizens include the following:

- Extending the definition of pen-register and trap/trace devices.

- Allowing law enforcement officers to obtain warrants for roving surveillance that targets a suspect in whatever location they might be found.

- Increasing the time period allowed for electronic surveillance and physical searches.

- No posterior notification need be given for clandestine searches of documents or property.

- Expanding the kinds of documents that the FBI can obtain from third parties without showing probable cause. (Schulhofer, 2005)

Each of these stipulations has direct applications to library patrons and their records.

Although rare in current circumstances, there are times when a student or parent or teacher/administrator may request information on a patron's reading records. These should always be denied for the reasons previously mentioned and because trust should be a core value for librarians. As mentioned before, there are times when a law enforcement officer may request such records. These must be accompanied by a legally enforceable order, either a subpoena or a warrant. Unlike a subpoena, a search warrant is issued if probable cause exists that evidence of criminal activity will be immediately secured. Therefore, a library staff member must comply with the order even if the library director has not been informed. The staff member should keep a record of the time of the search and any identifying credentials of the officials.

Since law enforcement searches are looking for a robust source of records and files that show activity, it may be best to keep such records to a minimum. Careful planning should be evident in the creation and maintenance of patron records. The following library procedures are included in the Guidelines for the University of Connecticut Law Library Staff protocol document:

The Library will not:

- Create unnecessary records of user library activity.

- Retain records that are not essential for the efficient operation of the library for any longer than required by state law. This includes data logs, digital records, and system backups. 
- Place confidential information on public view, such as posting online for overdue notices, discussing book titles checked out or requested with anyone other than the specific individual involved, or placing staff terminals so that users can see confidential information about other patrons on the screen. (Murray, 2003)

The purpose of these guidelines is to make searches of patron activity pointless or redundant. Circulation statistics and other rubrics can be kept without reference to what any particular person has read or borrowed. Bibliometrics that focus on what material is moving and what is being requested need not refer back to individual names and addresses.

\section{Censorship}

The question of censorship is an interesting one and it is important not to find oneself in disagreement with someone over what might only be a semantic difference. The first reaction of many people is that "nothing should be censored;" however, anyone who has had any real experience purchasing materials for a library knows that decisions have to be made about what to buy and considerations made as to who the likely readers will be. Moreover, there are classes of publications that have little or no legitimacy in a publicly funded library. One such example is Holocaust denial literature, which presents the Nazi's in a sympathetic light and maintains that the films of the concentration camps are falsified propaganda. Another is pseudoscientific literature such as Craniometry that purports to show biological evidence for racial inferiority, usually in regards to African and indigenous ethnic groups. Yet another is child pornography that puts forward methods for the sexual abuse and enslavement of minors. These are all areas that a responsible librarian "selects against" when making collection development decisions.

A counter point could be made that a research institution such as an academic library should spend some of what money is available to them on these subjects because there are patrons who might "study" these issues. It is important to note that, if these subjects are purchased as primary source literature and placed in the collection on that basis, then the reputation of these research or academic institutions will suffer. University and research institutions are evaluated on the perspicuity of their acquisition policies and attract qualified faculty and students, not to mention federal and state funding, based upon informed decisions. If these subjects are to be included, they should be in volumes that specifically preface them as questionable material.

These extreme cases aside, there are many examples of meaningful scholarly and other works that come under pressure by various groups for exclusion from a library's collection. In this respect a distinction can be made between self-censorship and the expurgation of library materials. Expurgation is understood in this context as any "deletion, excision, alteration, or editing" of library resources when done "for the purpose of censorship" (ALA.org, 2014). Expurgation is best understood as a denial of access to the relevant material of a patron's interest. This is usually what a person has in mind when they are thinking of the negative aspects of censorship. Self-censorship by contrast is when an individual subtly censors his/her decisions based upon a feeling that it would be expedient to avoid the material. This is usually due to a form of peer pressure or something that may be trending in the culture. Self-censorship more than likely happens to every person at some point in time. The best corrective is to adopt a written policy, developed through peer review, to protect works that exhibit the values of research and educational potential from elements that oppose these values based upon tradition or bias.

Another question that should be given careful consideration is the policy of filtered/unfiltered Internet. The earlier decisions about not prohibiting area access to children were developed in the pre-Internet era with print materials foremost in mind. The effects of streaming video of sexual interactions, often conducted in contexts of domination and submission, on those who are in the stages of pre-literacy has not yet been determined. Support for some sort of filtering could be inferred from guidelines 5 and 6 of the "Guidelines for ALCTS Members to Supplement the American Library Association Code of Ethics," developed specifically for collection development librarians:

- Promote the development and application of standards and professional guidelines.

- Establish a secure and safe environment for staff and users. (ALA.org, 1994)

Many libraries have a filtered Internet station available for use in the youth collection, and an unfiltered adult station. The adult station can be situated in the direct line of sight of the circulation desk. Patron complaints about Internet viewing should be referred to a library professional and should always be dealt with in a sincere and courteous manner.

Generally speaking censorship questions are more acute in the public library than in academic or special ones. There are a number of reasons for this, including the following: The public library is not primarily a research institution, the public library should have a family friendly environment, and the public library should hold the safety of its patrons as a high priority. Although academic library policies may not be as concerned about an all ages environment to the extent of their public counterparts, vigilance must be maintained as to the quality and relevance of the research materials that are collected. Some issues that both academic and public libraries share in common include the following:

- The importance of preserving print, digital, and other materials for future use.

- Access to a variety of points-of-view should be cultivated. 
- Areas for collaborative development such as meeting rooms should be made available.

- Confidentiality of library transactions and records.

All of these imply a certain degree of censoring, either the censoring of exclusive use and wear of materials, or the censoring of the domination of a single point-of-view, or the censoring of exclusive use of library space, or the censoring of the ability of various sources to view patron habits and reading interests.

With the terminology expressed in this way, a distinction can be made among four general attitudes toward materials that are being considered for a collection. Listed alphanumerically, they are:

A. Looking for reasons why materials should be selected

B. Looking for reasons why materials should not be selected

C. Neutrality toward materials

D. Bias pro or con toward materials

These are naturally occurring attitudes and they must be conditioned by an agreed upon collection development policy. This relationship can be represented by the following figure.

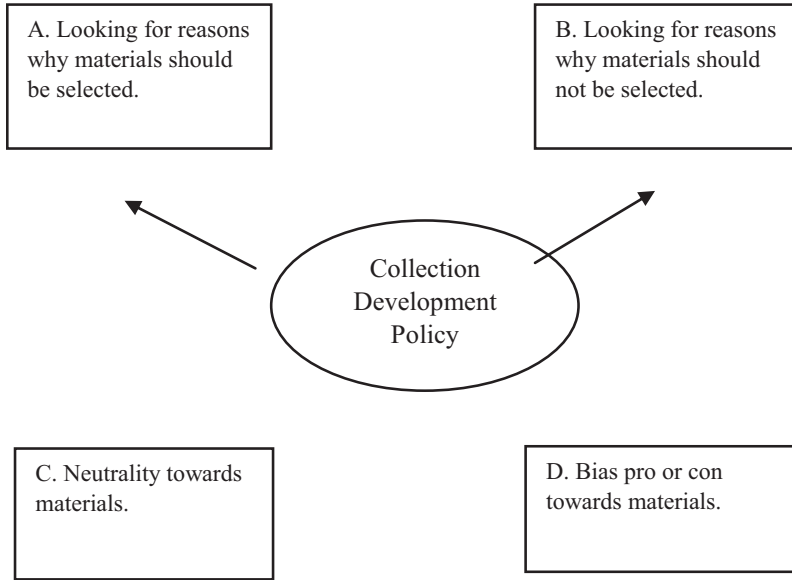

FIGURE 1 Four attitudes that are commonly displayed during the selection of materials. Arrows represent the direction of authority between an adopted policy and the attitudes.

"A" and "B" distinguish themselves from being special cases of " $D$ " by having a formal policy to which they conform. "C" can be further divided into different attitudes, as will be considered later. "A" and "B" are not mutually exclusive and an experienced collection development librarian should be able to perform them either sequentially or simultaneously. Although not elaborated in the context of this discussion, selection activities should be informed by an understanding of the needs and goals of the target population for a given library. Demographics should be collected on library patron group characteristics, such as age, level of income, and education level. A library's materials are developed first and foremost to serve the interests of the surrounding community (Figure 1).

\section{Some Considerations}

Overall it is important for librarians to exhibit what could be described as a circumspect neutrality when making collection development decisions. On the one hand, librarians should be for open access and freely available information. On the other hand librarians have to make decisions about what materials to purchase and to do their best to keep the library a safe place. Just as one would not allow an unhinged transient to prowl the children's section, so one would not ordinarily spend precious resources on Holocaust denial literature. If the selection of information materials was truly neutral, then the results of the process could not help people in the pursuit of their goals, and it could do no harm to them as well. Consider the following examples:

- A patron was approached at a graduate research library. Patron said that he was a student and that he was preparing a document on the Texas legislature. He was browsing government records on the 2009-2011 biennium session. Patron claimed he felt a lack of preparation for an assignment. The assignment established an educational context and the possibility of failing.

- At a university fine arts library, a patron said that she wished to become an actress. She was browsing plays to find a suitable piece to prepare for an audition. Patron claimed that she felt that she needed to have something polished in advance. This would help reinforce her confidence in the context of a competitive audition environment.

- At a branch of the Austin Public Library, a patron said that he was out of work. He was reading the public newspapers in the reading area. The patron was clearly searching for job openings in order to gain employment. His concerns were enhanced by time considerations since last employment.

What these examples have in common is a situation where people are searching for assistance in the pursuit of goals. In this context false or misleading information is not valuable, and could be used as evidence that the particular library is not a fit candidate for continued appropriations.

It is important to recognize that as more and more of a collection goes online, the less access there is for patrons who do not have a formal association with the library (and this usually means some sort of financial connection) because of the requirement for log-on credentials. This is particularly true in academic libraries due to the importance of online journals. As some have noted, the developing situation is similar to a return to the closed stacks policy of the 19th century. The opening of the stacks signaled the transition of the library into a social and community centered organization. (Dresang, 2006) It should come as no 
surprise that the gradual disappearance of the stacks into computer terminals raises questions about the future role of libraries.

\section{CONCLUSION}

Despite the many technological innovations that are currently sweeping the library and information profession, abiding issues remain. Questions concerning privacy and censorship and the way these concepts interact with collection development decisions continue to be areas of vital interest. Libraries have historically been protective of confidential information regarding patron records. Given the uncertainty of current Internet safeguards, librarians have an important role to play in providing a reasonable guarantee of privacy. Operating guidelines for dealing with over reaching government legislation should be established. Negative censorship practices such as the expurgation of library materials and self censorship should be avoided. The differences and similarities between academic and public libraries should be considered when selecting material for those collections. Information has value and can help or hinder those who seek information sources to further personal goals. Librarians should pursue selection policies that reflect the needs and interests of those community members that the institution serves.

The idea of libraries as that of places where patrons can view sources of information without the interference of a censoring or authoritative presence is a powerful one. Nevertheless, it is important to realize that absolute neutrality, if that is in fact possible, would entail many difficulties. The Internet makes clear on a daily basis that such a neutrality is the role that machines play. Machines are neither the enemy nor the advocate of those who use them. It is the role of librarians to be of assistance, and to select materials for information or entertainment value. Apart from the financial limitations that all librarians must deal with, there is also the duty of making personal decisions based upon training and experience. Not doing so would effectively outsource the collection development process to some other entity. And those entities, whether they are corporations, law enforcement, or machines, may have no tradition, respect, or value for the independence of the individual learner.

\section{REFERENCES}

ALA.org. (1994). Guidelines for ALCTS members to supplement the American Library Association code of ethics. Retrieved from http:// www.ala.org/alcts/resources/alaethics

ALA.org. (2002). Privacy: An interpretation of the Library Bill of Rights. Retrieved from http://www.ala.org/advocacy/intfreedom/ librarybill/interpretations/privacy

ALA.org. (2005). FBI used Patriot Act's administrative subpoena to get library records in Connecticut. Retrieved from http://www.ala.org/ Template.cfm?Section $=$ pressreleases\&template=/contentmanagement/ contentdisplay.cfm\&ContentID $=102669$

ALA.org. (2014). Expurgation of library resources. Retrieved from http://www.ala.org/advocacy/intfreedom/librarybill/interpretations/ expurgationlibrary

Dresang, E. (2006). Intellectual freedom and libraries: Complexity and change in the twenty-first century digital environment. Library Quarterly, 76, 169-192.

Issac, M. (2016). Explaining Apple's fight with the F.B.I., The New York Times. Retrieved from http://www.nytimes.com/2016/02/18/ technology/explaining-apples-fight-with-the-fbi.html

Murray, P. (2003). SPEC Kit 278: Library patron privacy. Washington, DC: ARL.

NISO. (2016). Consensus framework to support patron privacy in digital library and information systems. Retrieved from http://www.niso.org/ topics/tl/patron_privacy.html

Robertson, E. (2011). Fundamental right to read: Reader privacy protections in the US Constitution. University of Colorado Law Review, 82, 307-330.

Schulhofer, S. (2005). Rethinking the Patriot Act. New York, NY: Century Foundation Press.

Stanley v. Georgia 394 U.S. 557. (1969). Justia.com. Retrieved from http://supreme.justia.com/cases/federal/us/394/557/case.html

The USA Patriot Act. (2016). Department of Government and Justice Studies, Appalachian State University. Retrieved from http://gjs.appstate. edu/media-coverage-crime-and-criminal-justice/usa-patriot-act.html 